\title{
Energy Consumption and Greenhouse Gas Emissions During Ferromolybdenum Production
}

\author{
Wenjing Wei ${ }^{1,2}$ (Deter B. Samuelsson ${ }^{1} \cdot$ Anders Tilliander $^{1} \cdot$ Rutger Gyllenram $^{1,2} \cdot$ Pär G. Jönsson $^{1}$
}

Published online: 6 January 2020

(c) The Author(s) 2020

\begin{abstract}
Molybdenum is mainly used as an alloy material in the iron and steel industry and typically in the form of ferromolybdenum (FeMo). The current study aims to evaluate the energy consumption and greenhouse gas emissions (GHG) of four ferromolybdenum production cases using inventory inputs from a process model based on mass and energy conservations. The total energy required for producing 1 tonne of FeMo can vary between 29.1 GJ/t FeMo and 188.6 GJ/t FeMo. Furthermore, the corresponding GHG emissions differ from $3.16 \mathrm{tCO}_{2}$-eq/t FeMo to $14.79 \mathrm{tCO}_{2}$-eq/t FeMo. The main variances are from the mining and beneficiation stages. The differences in these stages come from the beneficiation degree (ore grade) and the mine type (i.e., co-product from copper mining). Furthermore, the mine type has a larger impact on the total energy consumption and GHG emissions than the beneficiation degree. More specifically, FeMo produced as co-product from copper mining has a lower environmental impact measured as the energy consumption and GHG emission among all the four cases. The inventory, consumed energy or associated GHG emission is independent on the initial ore grade and mine type in the downstream production stages such as roasting and smelting. Also, transport has the least impact on the energy consumption and GHG emission among all production stages.
\end{abstract}

Keywords Ferromolybdenum $\cdot$ Energy consumption $\cdot$ Greenhouse gas emission $\cdot$ Material balance $\cdot$ Energy balance

\section{Introduction}

Molybdenum is widely used as an alloy material in the iron and steel industry, and in particular in the stainless steel industry, in the form of ferromolybdenum (FeMo). Alloying with molybdenum contributes to a better corrosion resistance of iron and steel products. With increasing global attention to the climate change issue, it is assumed that molybdenum producers are facing a need for lowering the product's environmental impacts, such as the greenhouse gas (GHG)

The contributing editor for this article was Veena Sahajwalla.

Electronic supplementary material The online version of this article (https://doi.org/10.1007/s40831-019-00260-8) contains supplementary material, which is available to authorized users.

Wenjing Wei

wenjingw@kth.se

1 Department of Materials Science and Engineering, Royal Institute of Technology, Brinellvägen 23, 10044 Stockholm, Sweden

2 Kobolde \& Partners AB, Stockholm, Sweden emission $[1,2]$ to improve their sustainable profile in the alloy market.

Cradle-to-gate life cycle assessment (LCA) [3] is a systematic tool developed for assessing the environmental aspects associated with a product from resource extraction to the factory gate. Life cycle inventory (LCI) [4] is one of the execution steps in the LCA to account for the energy and resource flow within a defined boundary. To date, limited LCA and LCI studies have been published for molybdenum. The International Molybdenum Association (IMOA) completed a life cycle inventory [1] for three molybdenum-containing metallurgical products (roasted molybdenite concentrates, ferromolybdenum, and technical molybdic oxide briquette). IMOA's LCI study regards each production stage as a 'black box' with input and output datasets from several production sites, which cover $30 \%$ (if not specified, the default value is given as weight percent) of the world's total molybdenum production. Therefore, the consequent resource usage and environmental impacts results are reported as an industrial average level. For downstream customers like stainless steel manufacturers, lack of the plant-specific data on the molybdenum product results in 
difficulties when selecting a raw material supplier for their production processes, as well as to make life cycle assessment for their products.

Production inventory data from a specific plant or mine is usually not accessible for external parties. Therefore, a process model based on mass and energy balances was employed to resolve the issue and provides an alternative to estimate the plant inventory data. In comparison to the previously mentioned 'black box' model [1], the process model can be used as the reference source of LCI. Such process modeling efforts have been reported for several pyrometallurgical processes such as the metallothermic smelting of ferromolybdenum [5]; production of $\mathrm{MoO}_{2}$ from molybdenite using the looping-sulfide oxidation process [6]; ironmaking in a blast furnace [7]; steelmaking in an electric arc furnace [8-11]; lime production in a kiln [12]; ferronickel alloy processing in rotary kiln-electric furnace [13] and $\mathrm{MgO} / \mathrm{Mg}(\mathrm{OH})_{2}$ production [14]. The previously mentioned material and energy balance models mainly evaluates the energy consumption, material recovery, and GHG emission.

The focus of the present study is to determine the energy consumption and GHG emission of ferromolybdenum produced by pyrometallurgical processes and to estimate the contribution to the GHG emissions from the various process stages. Beside developing a base for estimating the LCI of different production routes, the results will also create an understanding on which GHG emission can be influenced through technical and organizational development, change of technology, etc. In doing this, a process calculation model was used to estimate the plant-specific process data and to compare the FeMo product with respect to the differences in beneficiation degree (the ratio of concentrate grade to raw ore grade), mine type, and required processing stages.

\section{Production Process of Ferromolybdenum}

\section{Mining and Beneficiation}

Molybdenum exists as different minerals, such as molybdenite $\left(\mathrm{MoS}_{2}\right)$, wulfenite $\left(\mathrm{PbMoO}_{4}\right)$, and powellite $\left(\mathrm{CaMoO}_{4}\right)$. At present, the main commercial source is molybdenite which commonly is found and extracted in China, the United States, and Chile [15]. Molybdenum minerals are mined in both open pit and underground mines. The molybdenum ore grade from primary mine is in general low, containing approximately 0.1 to $0.3 \% \mathrm{Mo}$. The molybdenum ore derived as a co-product from copper mine has an even lower grade, which contains 0.01 to $0.05 \%$ Mo [16].

The mining stage can be further divided into two parts: extraction and material handling. The first part extraction aims to expose the ore from the overburden and it involves several activities such as drilling, blasting, digging, and ventilation. The extraction process may require fuel and electricity running equipment for instance drills, shovels, motors, pumps, haul trucks, etc. The second part material handling includes the transport of the extracted ore to the ore processing site and the transport of the waste from the mine to the disposal site. Material handling part may require diesel fuel powered mobile equipment (haul truck, loader, dozer) and electric equipment (load-haul-dumper, hoist, conveyors, and pump).

The beneficiation stage is arranged in different flowsheets including crushing, grinding, and floatation. Molybdenite is released from gangue and reduced into coarse particles by using crushers. Through the grinding process, the ore material is further reduced into fine particles by a grinder or a mill. In the following floatation step, the ground ore powder is mixed with certain surface-active chemicals to make the valuable metallic minerals rise with the air bubbles to the water surface and thus separates ore from the gangue. The typical concentrate after the beneficiation process results in a product containing $45-60 \%$ Mo [17], while the rest is made up of impurities such as silica, iron, and copper.

Molybdenum is extracted not only from primary mining, but also as a co-product from copper mining. About $50 \%$ of the world's molybdenum production is based on a co-product from copper mining [18]. During the copper beneficiation process, liquid chemicals are added to aid floating molybdenite, which is then separated from the copper containing minerals. This flotation step is repeated several times, where the molybdenite subsequently goes into a separate floatation cycle for further concentration. Sometimes, an acid leaching step is required to remove the impurities, such as copper, to raise the purity of molybdenite concentrate.

\section{Roasting}

Roasting is performed in a multiple hearth, vertical furnace with the purpose to remove sulfur from the mineral. The roasting furnace is typically designed with 8 levels and running at an operating temperature not higher than $750{ }^{\circ} \mathrm{C}$ [17]. The furnace temperature should be strictly controlled to minimize molybdenum losses due to sublimation. The injected air flows upwards from the bottom of the roaster, while the concentrate enters the top of the roaster in a counter current flow. Initially, oil and moisture are removed from the concentrate. Then, the main roasting reactions occur in the subsequent hearths at a temperature of $600-650{ }^{\circ} \mathrm{C}$ [16]. As the roasting reaction is exothermic (Table 1-Eq. 2), the reaction heat can provide a sufficient heat to reach the working temperature in the furnace, and excess heat may require large amounts of cooling air to maintain a proper furnace temperature $[16,17]$.

After a completed roasting process, the molybdenum concentrate $\left(\mathrm{MoS}_{2}\right)$ is converted into a roasted molybdenite 
Table 1 Chemical reactions during ferromolybdenum production

\begin{tabular}{ll}
\hline Typical reactions in a roaster & \\
$\mathrm{H}_{2} \mathrm{O}(\mathrm{l})=\mathrm{H}_{2} \mathrm{O}(\mathrm{g}), \Delta \mathrm{H}_{298}=43.39 \mathrm{~kJ} / \mathrm{mol}$ & Equation 1 \\
$\mathrm{MoS}_{2}+3.5 \mathrm{O}_{2}=\mathrm{MoO}_{3}+2 \mathrm{SO}_{2}, \Delta \mathrm{H}_{298}=-1086.08 \mathrm{~kJ} / \mathrm{mol}$ & \\
Typical reactions in an electric furnace & Equation 2 \\
$\mathrm{MoO}_{3}+2 \mathrm{Al}=\mathrm{Mo}+2 \mathrm{Al}_{2} \mathrm{O}_{3}, \Delta \mathrm{H}_{298}=-928.4 \mathrm{~kJ} / \mathrm{mol}$ & Equation 3 \\
$2 \mathrm{MoO}_{3}+3 \mathrm{Si}=2 \mathrm{Mo}+3 \mathrm{SiO}_{2}, \Delta \mathrm{H}_{298}=-1242.2 \mathrm{~kJ} / \mathrm{mol}$ & Equation 4 \\
$2 \mathrm{Fe}_{2} \mathrm{O}_{3}+\mathrm{Si}=4 \mathrm{FeO}+\mathrm{SiO}_{2}, \Delta \mathrm{H}_{298}=-348 \mathrm{~kJ} / \mathrm{mol}$ & Equation 5 \\
$2 \mathrm{FeO}+\mathrm{Si}=2 \mathrm{Fe}+\mathrm{SiO}_{2}, \Delta \mathrm{H}_{298}=-367.01 \mathrm{~kJ} / \mathrm{mol}$ & Equation 6 \\
\hline
\end{tabular}

Table 1 is based on data from reference [19]

concentrate (RMC), or technical grade molybdenum oxide, consisting more than $50 \%$ Mo, where $90 \%$ molybdenum is present in the form of $\mathrm{MoO}_{3}$ and the rest is in the form of $\mathrm{MoO}_{2}$ [17]. Most of the sulfur in the raw ore is converted into $\mathrm{SO}_{2}$ gas which can be utilized to produce sulfuric acid as a co-product.

\section{Smelting}

In the production of FeMo, the RMC is processed in an electric furnace at high temperatures, between 1760 and $2100{ }^{\circ} \mathrm{C}$ depending on the smelting time [17]. The RMC is mixed with iron oxide and slag formers such as lime and fluorspar. Thereafter, it is melted and subsequently reduced by reduction agents such as carbon, silicon, aluminum in a metallothermic process. However, most of the FeMo is produced by using aluminum and silicon as the reducing agents, due to the requirement of low carbon $(\mathrm{C}<0.5 \%)$ in the final product [17]. In some case, carbon is used as the reduction agent to lower the production cost, which results in a product containing maximum $2 \%$ carbon [16]. The molybdenum content in the FeMo may vary in the range of 55 to $70 \%$ [16] and may contain impurities such as $\mathrm{Si}, \mathrm{Cu}, \mathrm{P}, \mathrm{S}$, and $\mathrm{Pb}$. The slag consists of $60-70 \% \mathrm{SiO}_{2}, 9-13 \% \mathrm{Al}_{2} \mathrm{O}_{3}, 7-11 \% \mathrm{FeO}$, and $6-9 \% \mathrm{CaO}$ [17]. The chemical reactions that occur in the electric furnace are given in Eqs. 3-6 in Table 1.

\section{Methodology}

\section{Analysis of Energy Consumption and Greenhouse Gas Emissions}

In order to evaluate ferromolybdenum's energy consumption and greenhouse gas emissions, the difference in beneficiation degrees (the ratio of concentrate grade to raw ore grade), mine types, and processing stages are studied. A model based on mass and energy balance is used to provide the inventory analysis for the impact evaluation. Figure 1 illustrates the boundary of the model system for a FeMo production. It starts from extraction of molybdenum ore, through ore processing and roasting to the manufacturing of FeMo. The model is also taking into consideration of production of auxiliary materials lime, steel scrap, iron ore pellets, FeSi, and aluminum. Thus, it provides a cradle-togate assessment of the primary FeMo production throughout the whole supply chain system. One tonne of FeMo is chosen as the calculation base in the process model. FeMo is assumed to contain $60 \% \mathrm{Mo}$, which represents a standard

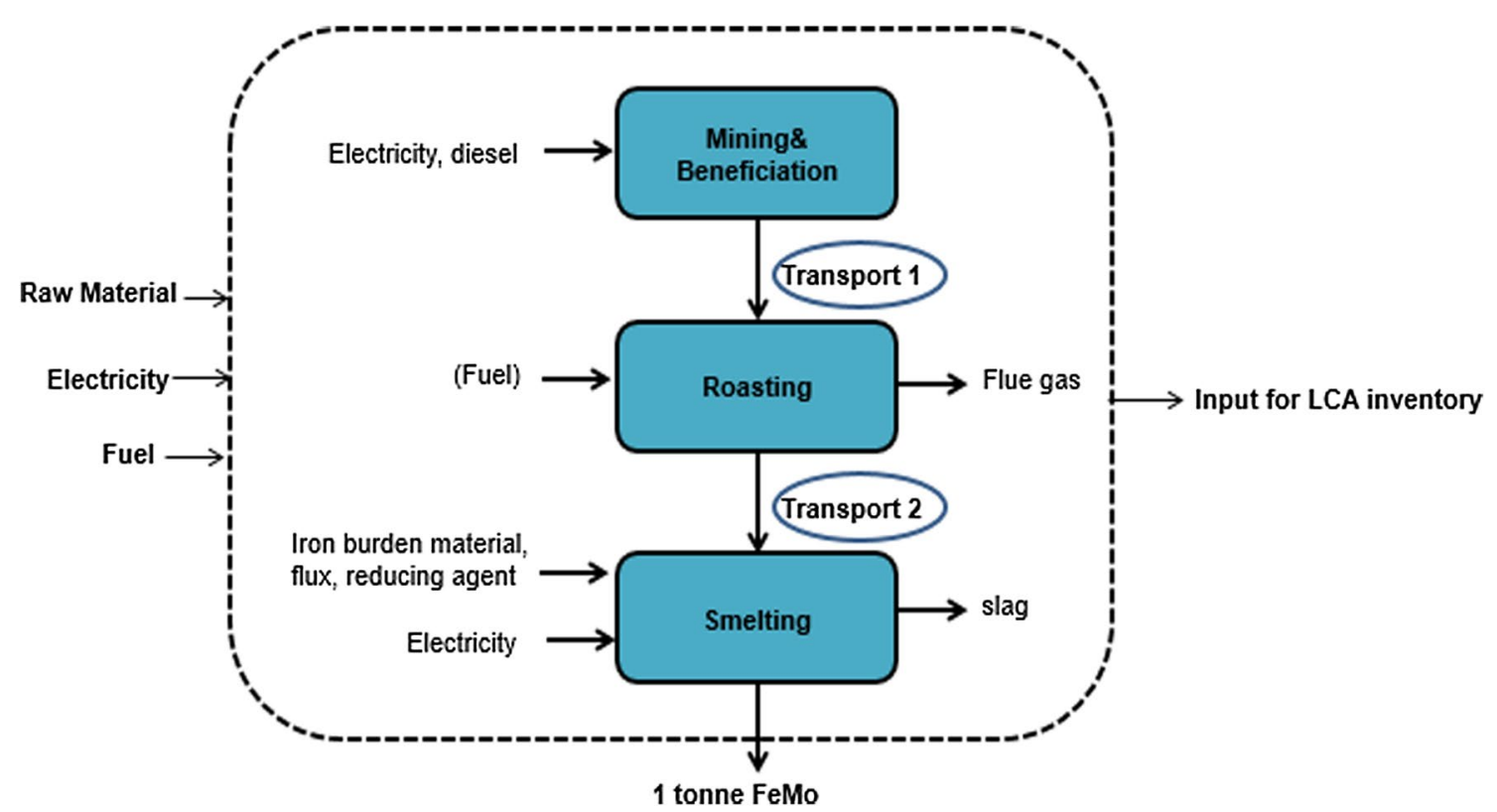

Fig. 1 Model boundary of producing ferromolybdenum (Color figure online) 
and commercial FeMo quality [17]. Auxiliary raw materials such as lime and reduction agents are assumed to be produced at a relatively close distance so that the influence of their transport can be omitted. Furthermore, the electricity distribution loss, reuse of $\mathrm{SO}_{2}$ in the acid plant, and use of water and explosives in the mining process are excluded in this study.

\section{Description of the Process Model}

A process model was developed together with the underlying assumptions to obtain the inventory data for different production stages. The process model follows the principle of mass and energy conservations under steady-state conditions. It is assumed that all input gases, fuels, raw materials are charged at an ambient temperature $\left(25^{\circ} \mathrm{C}\right)$, which means that no sensible heat is added into the system. Also, the gases in the model are following ideal gas behavior.

To simplify the modeling of the roasting process, it is firstly assumed that all molybdenum is present in the form of $\mathrm{MoO}_{3}$ in the RMC which means no $\mathrm{MoO}_{2}$ is formed during process. Meanwhile, all sulfur is converted into a $\mathrm{SO}_{2}$ gas after roasting. Secondly, the moisture present in the ore is assumed not reacting with the metal and all vaporized into the flue gas. Besides, the remaining components in the ore such as $\mathrm{Cu}, \mathrm{Pb}, \mathrm{P}, \mathrm{Ca}$ and $\mathrm{Si}$ remain in the outgoing roasted concentrate. In addition, the discharged RMC and the flue gas leave the furnace at $650{ }^{\circ} \mathrm{C}$. Also, it is assumed that no sublimation of $\mathrm{MoO}_{3}$ occurs at this temperature. Thirdly, assuming there is no extra heating source in the roasting process as the matter of fact that the roasting reaction theoretically can provide a significant and sufficient heat for process. Furthermore, in the present model, it is taking into account a part of air as cooling air for maintaining the temperature of the furnace and outgoing products at $650{ }^{\circ} \mathrm{C}$. At the end, the enthalpy of mixing different chemical compounds $\left(\mathrm{MoO}_{3}, \mathrm{Cu}, \mathrm{P}\right.$ etc.) for the $\mathrm{RMC}$ is considered as zero, thus the enthalpy of RMC is determined by Eqs. 7 and 8. This applies to the flue gas, the slag, and the FeMo as well.

$\Delta \mathrm{H}_{i}=\mathrm{C}_{i} \mathrm{~m}_{i} \Delta \mathrm{T}$

$\Delta \mathrm{H}_{\text {mixture }}=\sum \mathrm{x}_{i} \Delta \mathrm{H}_{i}$

$\Delta \mathrm{H}_{\mathrm{i}}$ is the change of enthalpy for the compound $i . \mathrm{C}_{i}$ is the specific heat capacity of the compound $i$ at a constant pressure. Thermodynamic data are from [19]. $\mathrm{m}_{i}$ is the mass of the compound $i . \Delta \mathrm{T}$ is the temperature difference between the reference temperature $\left(25^{\circ} \mathrm{C}\right)$ and the outlet temperature. $\Delta \mathrm{H}_{\text {mixture }}$ is the enthalpy change of the liquid, gas, and solid mixture. It refers to the energy required to heat up RMC, flue gas, FeMo, and slag from reference temperature to outgoing temperature in the present work. $\mathrm{x}_{\mathrm{i}}$ is the molar fraction of the compound $i$.

It is assumed that the smelter operates as an electric arc furnace with a 58\% energy efficiency [20]. Other than RMC, the other charged materials in the smelter include two ironbased materials (iron ore and steel scrap), reduction agents (FeSi and $\mathrm{Al}$ ) and lime. The fluorspar is sometimes charged to reduce the viscosity of the slag. In the present model, it is assumed that the amount of fluorspar is small enough so that it can be neglected [5]. To facilitate the modeling of the smelting process, a charging ratio between the roasted concentrates and iron ore, aluminum, lime (650:309:58:80) [21] is assumed. Addition of other raw materials such as steel scrap and FeSi will be calculated through the process model. Then, $\mathrm{Fe}_{2} \mathrm{O}_{3}$ in iron ore is considered as partly reduced; $70 \%$ reduced to $\mathrm{Fe}$ and $30 \%$ reduced to $\mathrm{FeO}$. This distribution ratio can keep the concentration of $\mathrm{FeO}$ in the slag around $10 \%$ which is a reasonable level according to the published FeMo slag analysis [5]. Moreover, the slag will be recycled back to the process if the molybdenum is more than $0.3 \%$ [17], so in this study the concentration of molybdenum in the slag is assumed to be $0.3 \%$. In addition, the model does not take the dust loss into account. Finally, it is assumed that the tapped molten FeMo and the slag are maintained at the same temperature of $2000{ }^{\circ} \mathrm{C}$ for energy calculation [5].

The following equations in Table 2 may express mass and energy conservation in a roaster and an electric smelter:

The greenhouse gas emission is estimated through Eq. 21 .

$\mathrm{EM}_{i}=\mathrm{EF}_{i} \times \mathrm{Q}$

$\mathrm{EM}_{i}$ is the emission source $i, \mathrm{EF}_{i}$ is the emission factor (EF) of pollutant $i, \mathrm{Q}$ is the amount of emission source such as energy, fuel, and ingoing materials.

\section{Results}

In this study, four cases representing different molybdenum concentrates were evaluated based on a developed process model. The following results are presented as (1) inventory data for FeMo production; a comparison of cases A, B, and $\mathrm{C}$ with respect to (2) effect of beneficiation degree on energy consumption and GHG emission; a comparison of cases C and D with respect to (3) effect of mine type on energy consumption and GHG emission; and (4) effect of process stage on energy consumption and $G H G$ emission.

\section{Inventory Data for FeMo Production}

The energy consumption and greenhouse gas emissions during the manufacturing of FeMo are dependent on a couple of factors. FeMo alloys produced from four concentrate 
Table 2 Mass and energy conservation in the roaster and the electric smelter

\begin{tabular}{|c|c|}
\hline \multicolumn{2}{|l|}{ Reactions in a roaster } \\
\hline $\mathrm{M}_{\mathrm{R}, \text { in }}=\mathrm{M}_{\mathrm{R}, \text { out }}$ & Equation 9 \\
\hline $\mathrm{M}_{\mathrm{R}, \mathrm{in}}=\mathrm{M}_{\mathrm{R}, \mathrm{ORE}}+\mathrm{M}_{\mathrm{R}, \mathrm{AIR}}$ & Equation 10 \\
\hline$M_{R, \text { out }}=M_{R, R M C}+M_{R, G A S}$ & Equation 11 \\
\hline $\mathrm{E}_{\mathrm{R}, \mathrm{in}}=\mathrm{E}_{\mathrm{R}, \mathrm{out}}$ & Equation 12 \\
\hline $\mathrm{E}_{\mathrm{R}, \mathrm{in}}=\mathrm{E}_{\mathrm{R}, \mathrm{EX}}$ & Equation 13 \\
\hline $\mathrm{E}_{\mathrm{R}, \text { out }}=\mathrm{E}_{\mathrm{R}, \mathrm{RMC}}+\mathrm{E}_{\mathrm{R}, \mathrm{EN}}+\mathrm{E}_{\mathrm{R}, \mathrm{GAS}}$ & Equation 14 \\
\hline \multicolumn{2}{|l|}{ Reactions in an electric furnace } \\
\hline $\mathrm{M}_{\mathrm{E}, \text { in }}=\mathrm{M}_{\mathrm{E}, \text { out }}$ & Equation 15 \\
\hline$M_{E, i n}=M_{E, R M C}+M_{E, I R O N}+M_{E, S C R A P}+M_{E, A L}+M_{E, S I}+M_{E, L I M E}$ & Equation 16 \\
\hline$M_{E, \text { out }}=M_{E, F M}+M_{E, S L A G}$ & Equation 17 \\
\hline $\mathrm{E}_{\mathrm{E}, \mathrm{in}}=\mathrm{E}_{\mathrm{E}, \text { out }}(18)$ & Equation 18 \\
\hline $\mathrm{E}_{\mathrm{E}, \mathrm{in}}=\mathrm{E}_{\mathrm{E}, \mathrm{EL}}+\mathrm{E}_{\mathrm{E}, \mathrm{EX}}$ & Equation 19 \\
\hline $\mathrm{E}_{\mathrm{E}, \text { out }}=\mathrm{E}_{\mathrm{E}, \mathrm{FM}}+\mathrm{E}_{\mathrm{E}, \mathrm{SLAG}}+\mathrm{E}_{\mathrm{E}, \mathrm{LOSS}}$ & Equation 20 \\
\hline $\mathrm{M}_{i, \text { in }}$ & $\begin{array}{l}i=\mathrm{R} \text { or } \mathrm{E} ; \mathrm{R} \text { represents the roaster and } \mathrm{E} \text { stands for the electric arc } \\
\text { furnace. } \mathrm{M}_{i \text {, in }} \text { represents the total mass input in the roaster or in the } \\
\text { electric arc furnace }\end{array}$ \\
\hline $\mathrm{M}_{i, \text { out }}$ & $\begin{array}{l}i=\mathrm{R} \text { or } \mathrm{E} ; \mathrm{R} \text { represents the roaster and } \mathrm{E} \text { stands for the electric arc } \\
\text { furnace. } \mathrm{M}_{i, \text { out }} \text { represents the total mass output in the roaster or in } \\
\text { the electric arc furnace }\end{array}$ \\
\hline $\mathrm{E}_{i, \text { in }}$ & $\begin{array}{l}i=\mathrm{R} \text { or } \mathrm{E} ; \mathrm{R} \text { represents the roaster and } \mathrm{E} \text { stands for the electric arc } \\
\text { furnace. } \mathrm{E}_{i, \text { in }} \text { represents the total energy input in the roaster or in the } \\
\text { electric arc furnace }\end{array}$ \\
\hline $\mathrm{E}_{i, \text { out }}$ & $\begin{array}{l}i=\mathrm{R} \text { or } \mathrm{E} ; \mathrm{R} \text { represents the roaster and } \mathrm{E} \text { stands for the electric arc } \\
\text { furnace. } \mathrm{E}_{i, \text { out }} \text { represents the total energy output in the roaster or in } \\
\text { the electric arc furnace }\end{array}$ \\
\hline $\mathbf{M}_{\mathrm{R}, j}$ & $\begin{array}{l}j=\text { ORE, AIR, RMC, GAS; } \mathrm{M}_{\mathrm{R}, j} \text { represents the mass of raw ore } \\
\text { (ORE), air (AIR), roasted molybdenum concentrate (RMC), and } \\
\text { flue gas (GAS) in the roaster, respectively }\end{array}$ \\
\hline $\mathrm{E}_{\mathrm{R}, j}$ & $\begin{array}{l}j=\mathrm{EX}, \mathrm{RMC}, \mathrm{EN}, \mathrm{GAS} ; \mathrm{E}_{\mathrm{R}, \mathrm{j}} \text { represents the chemical energy released } \\
\text { or required from exothermic reaction }(\mathrm{EX}), \text { roasted molybdenum } \\
\text { concentrate }(\mathrm{RMC}), \text { endothermic reaction }(\mathrm{EN}) \text {, and flue gas }(\mathrm{FG}) \\
\text { in the roaster, respectively }\end{array}$ \\
\hline $\mathrm{M}_{\mathrm{E}, j}$ & $\begin{array}{l}j=\text { RMC, IRON, SCRAP, AL, SI, LIME, FM, SLAG; } \mathrm{M}_{\mathrm{E}, \mathrm{j}} \text { represents } \\
\text { the mass of roasted molybdenum concentrate }(\mathrm{RMC}), \text { iron ore } \\
\text { (IRON), scrap (SCRAP), aluminum (AL), ferrosilicon }(\mathrm{SI}) \text {, lime } \\
\text { (LIME), ferromolybdenum (FM), and slag (SLAG) in the electric } \\
\text { arc furnace, respectively }\end{array}$ \\
\hline $\mathrm{E}_{\mathrm{E}, j}$ & $\begin{array}{l}j=\text { EL, EX, FM, SLAG, LOSS; EE, } j \text { represents the electricity (EL), } \\
\text { the energy released or required from exothermic reaction (EX), } \\
\text { ferromolybdenum (FM), the slag (SLAG), and energy loss in the } \\
\text { electric arc furnace, respectively }\end{array}$ \\
\hline
\end{tabular}

through pyrometallurgy production processes are selected as case studies for examining the influence of different factors such as process stage, beneficiation degree, etc. on the energy consumption and GHG emissions. The four cases are denoted as A, B, C, and D. In Table 3, the basic information of the four cases is shown.

Based on Table 3, the following assumptions were made in carrying out the energy consumption and greenhouse gas emission calculations for producing FeMo:
(1) The energy consumption for case A during mining and beneficiation is estimated through each equipment's yearly working hours, engine power, load factor, yearly production, etc. [see details in electronic supplementary material (ESM), Tables 1 and 2]. The energy consumption data during the mining and beneficiation process are not accessible for cases B, C, and D due to the lack of information of plant data. A previous study has indicated that the degraded ore can significantly affect the energy consumption and greenhouse gas emission, since additional energy must be consumed during 
Table 3 Information of four molybdenum concentrates $[15$, $18,22-27]$

\begin{tabular}{lllllll}
\hline Case & $\begin{array}{l}\text { Mo annual pro- } \\
\text { duction (tonne) }\end{array}$ & $\begin{array}{l}\text { Share of the } \\
\text { world's produc- } \\
\text { tion }\end{array}$ & $\begin{array}{l}\text { Main production } \\
\text { and mine location }\end{array}$ & Ore grade & $\begin{array}{l}\text { Concen- } \\
\text { trate grade }\end{array}$ & $\begin{array}{l}\text { Ben- } \\
\text { eficiation } \\
\text { degree }^{\mathrm{a}}\end{array}$ \\
\hline $\mathrm{A}$ & 11,900 & 4.2 & Mo mine (USA) & 0.03 & 58 & 1933 \\
$\mathrm{~B}$ & 16,270 & 5.8 & Mo mine (China) & 0.115 & 51 & 443 \\
$\mathrm{C}$ & 23,130 & 8.2 & Mo mine (USA) & 0.21 & 53 & 252 \\
$\mathrm{D}$ & 11,500 & 4.1 & Cu mine (USA) & 0.057 & 55 & 965 \\
\hline
\end{tabular}

${ }^{\mathrm{a}}$ Beneficiation degree $=$ concentrate grade: the ore grade the mining and beneficiation processes to remove the unwanted materials in the ore [28]. Here, it is assumed that the energy consumption during the mining and beneficiation stages proportional to the beneficiation degrees are listed in Table 3. The energy consumption from the mining and beneficiation stages for cases B, $\mathrm{C}$, and $\mathrm{D}$ can be derived based on this assumption.

(2) For case D, molybdenum was extracted as a co-product from a copper mine. The energy consumption during the copper mining and beneficiation stages was estimated based on reported data [29]. Here, the energy consumption and environmental impact were allocated to the co-product molybdenum based on mass value rather than economic value, because economic value is highly influenced by the volatility of the metal market. The average production mass ratio of molybdenum to copper during 5 years is 3:100 [30], which is used as the allocation factor in this study. Also, molybdenum is separated during the copper's beneficiation process. This means that the energy consumption during the mining and beneficiation will include two parts. One part is from the allocation of copper mining and beneficiation while the other part is from molybdenite's further floatation cycle, which usually accounts for $4 \%$ of the total energy consumption in mining and ore processing [31].

(3) Transport distances between each processing site were estimated based on public information [24, 32, 33]. Moreover, the energy intensities for the different transport modes were calculated by using the average freight energy intensity values from the International Energy Agency [34]. It is assumed that only diesel was consumed during the transportation by rail and by ship. Also, the conversion factor of energy consumption during transportation is taken from a public source (see ESM, Table 3). Distances shorter than $50 \mathrm{~km}$ have a relatively low impact and were therefore not considered and marked as "N.C." in Table 4.

(4) Cases A, C, and D use the emission factors from electricity production in the USA, which is mainly based on coal $(69 \%)$ and natural gas (29\%) combustion [35]. The emission factors of electricity together with other sources used in the presented study are provided in ESM-Table 3. Emission of $\mathrm{CH}_{4}$ and the $\mathrm{N}_{2} \mathrm{O}$ emissions can be converted to $\mathrm{CO}_{2}$ equivalents $\left(\mathrm{CO}_{2}\right.$-eq $)$ based on the global warming potential (GWP) values

Table 4 Inventory data for one tonne FeMo $(60 \% \mathrm{Mo})$ production

\begin{tabular}{|c|c|c|c|c|c|}
\hline \multicolumn{2}{|l|}{ Process } & \multirow{2}{*}{$\begin{array}{l}\text { Case A (Mo mine) } \\
152,304\end{array}$} & \multirow{2}{*}{$\frac{\text { Case B (Mo mine) }}{39,760}$} & \multirow{2}{*}{$\begin{array}{l}\text { Case C (Mo mine) } \\
21,762\end{array}$} & \multirow{2}{*}{$\begin{array}{l}\text { Case D (Cu mine }) \\
55\end{array}$} \\
\hline Mining and benefi- & Diesel (MJ) & & & & \\
\hline ciation & Electricity (MJ) & 10,506 & 2743 & 1501 & 3536 \\
\hline Transport 1 & & $\begin{array}{l}\text { Rail transport } \\
3500 \mathrm{~km}\end{array}$ & N.C & $\begin{array}{l}\text { Rail transport } \\
1450 \mathrm{~km}\end{array}$ & $\begin{array}{l}\text { Rail transport } \\
1600 \mathrm{~km}\end{array}$ \\
\hline Roasting & Air (kg) & $\underline{9033}$ & $\underline{8612}$ & $\underline{8388}$ & $\underline{8540}$ \\
\hline Transport 2 & & N.C & N.C & $\begin{array}{l}\text { Sea transport } \\
7000 \mathrm{~km}\end{array}$ & N.C \\
\hline \multirow[t]{6}{*}{ Smelting } & Iron scrap (kg) & 114 & 92 & 111 & 114 \\
\hline & Iron ore $(\mathrm{kg})$ & 437 & 488 & 450 & 437 \\
\hline & Lime (kg) & 113 & 113 & 113 & 113 \\
\hline & Aluminum (kg) & 82 & 92 & 85 & 82 \\
\hline & FeSi75 (kg) & $\underline{376}$ & $\underline{379}$ & $\underline{377}$ & $\underline{376}$ \\
\hline & Electricity (MJ) & $\underline{3630}$ & 4389 & $\underline{3855}$ & $\underline{3635}$ \\
\hline
\end{tabular}

Underlined values are calculated outputs from the process model 
from the Intergovernmental Panel on Climate Change fifth assessment report [36], where $\mathrm{GWP}_{100}\left(\mathrm{CH}_{4}\right)=28$, $\mathrm{GWP}_{100}\left(\mathrm{~N}_{2} \mathrm{O}\right)=265$.

(5) It is assumed that all cases use the same quality auxiliary raw materials in their processes, including lime, iron ore, scrap, $\mathrm{FeSi}$, and aluminum. In other words, the chemical analysis, energy requirement, and emission factor when producing these raw materials are assumed to be the same in all cases (see ESM-Tables 3 and 4). Other than the concentration of molybdenum, the chemical compositions of other components in the raw concentrate are described in online source ESMTable 4. In the raw concentrate, the molar ratio of sulfur to molybdenum in the raw ore is assumed to be 2 in the ore concentrate, as the main components in the ore is $\mathrm{MoS}_{2}$. Also, minor components of elements such as $\mathrm{Cu}$, $\mathrm{Pb}, \mathrm{P}, \mathrm{CaO}$, and $\mathrm{SiO}_{2}$ are taken from literature data [17, $25,37]$. The rest is balanced with moisture.

According to the previously described conditions and the calculation results from a process model, an inventory table of producing one metric tonne FeMo $(60 \% \mathrm{Mo})$ is shown in Table 4 . The inventory marked with an underline represents the calculation outputs from the process model while the other inventory data are generated from Table 2 and assumptions. In addition, it should be mentioned again that case D represents a co-product from copper mine. An example of case A's calculation result is expressed in the online source (see ESM-Tables 5 and 6).

\section{Effects of Ore's Beneficiation Degree on Energy and GHG Emission}

The stage-by-stage energy consumption and greenhouse gas emission results from model calculation of producing FeMo (60\% Mo) are illustrated in Fig. 2.

As shown in Table 3, the ore's beneficiation degree (the ratio of concentrate grade: raw ore grade) in case A (1933) is higher than in case B (443) and case C (252). The decrease in beneficiation degree will result in a reduction of the overall energy consumption from $188.6 \mathrm{GJ} / \mathrm{t}$ FeMo to $50.2 \mathrm{GJ} / \mathrm{t}$ FeMo, as well as a decrease in the associated GHG emission from $14.79 \mathrm{tCO}_{2}$-eq/t FeMo to $4.69 \mathrm{tCO}_{2}$-eq/t FeMo. The main influential stage is the mining and beneficiation stages, since a higher beneficiation degree requires a higher additional energy to remove the unwanted gangue material. This consequently results in a higher associated GHG emission value, as $93 \%$ of the energy consumed during the mining and ore processing stages is from fossil fuel diesel (see ESM-Tables 1 and 2).

The concentrate grade for cases $\mathrm{A}, \mathrm{B}$, and $\mathrm{C}$ is in the range of $51-58 \%$, while the ore grade is between 0.03 and $0.21 \%$. The beneficiation degree, in accordance with the

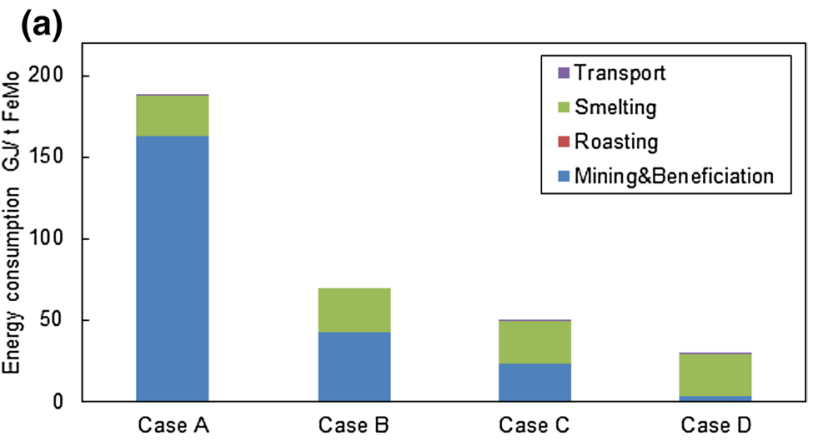

(b)

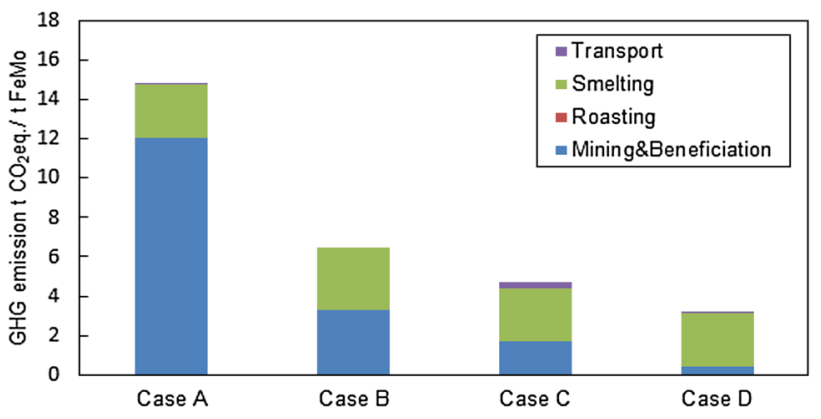

Fig. 2 Stage-by-stage results for producing one tonne of FeMo a energy consumption, b GHG emission (Color figure online)

definition (the ratio of concentrate grade:raw ore grade) is therefore essentially determined by the initial ore grade. When the ore grade contains $0.03 \% \mathrm{Mo}$ (case A), the energy output during mining and beneficiation stages accounts for about $86 \%$ of the overall energy consumption $(188.6 \mathrm{GJ} / \mathrm{t}$ FeMo) and $81 \%$ of the total GHG emission $\left(14.79 \mathrm{tCO}_{2}\right.$-eq/t FeMo). Furthermore, for an ore grade of $0.21 \% \mathrm{Mo}$ (case C) these stages account for $46 \%$ of the overall energy consumption (50.2 GJ/t FeMo) and 37\% of total gas emission (4.69 $\mathrm{tCO}_{2}$-eq/t FeMo). This agrees with the results from Norgate [28], who reported that when the metal ore grade is below $1 \%$, the effect of additional energy and associated greenhouse gas emissions due to deteriorated ore will be significant. The downstream molybdenum roasting and smelting processes are not affected by the ore grade, since the generated concentrate grade during the ore processing has a relatively constant value as is independent on the raw ore grade.

\section{Effects of Mine Type on the Energy and GHG Emissions}

Around 50\% of the global molybdenum production is from co-products from copper mining [18]. In the following, a comparison is made between case $\mathrm{D}$ produced as a co-product from a copper mine and case $\mathrm{C}$ where molybdenum is produced from primary molybdenum mine. As shown in 
Table 3, the beneficiation degree in case D (965) is higher than in case $\mathrm{C}$ (252). Although case D has a higher beneficiation degree, the total energy consumption and GHG emissions of producing one tonne FeMo are smaller than for case $\mathrm{C}$, which are $29.1 \mathrm{GJ} / \mathrm{t} \mathrm{FeMo}$ and $3.16 \mathrm{tCO}_{2}$-eq/t FeMo, respectively. This is due to the allocation of energy based on the mass ratio of copper and molybdenum in case $\mathrm{D}$, which consequently leads to a reduction of the GHG emission as well. As described earlier, the production mass ratio of molybdenum to copper, the allocation factor 3:100 was used in the study. It indicates that the mine type has a more influential impact on the total energy and GHG emission than the beneficiation degree has.

\section{Effect of Production Stage on the Energy and GHG Emission}

As the analysis results for the four cases suggested, the energy consumption during the mining and beneficiation stages varies from 3.6 GJ/t FeMo to $162.8 \mathrm{GJ} / \mathrm{t}$ FeMo, or between 12 and $86 \%$ of the overall energy consumption. The associated GHG emissions for these stages range from $0.46 \mathrm{tCO}_{2}$-eq/t FeMo to $12.06 \mathrm{tCO}_{2}$-eq/t FeMo and the emission contribution varies from 14 to $81 \%$. The differences between cases derive from the beneficiation degree and the allocation of co-products in the copper mine.

Apart from the mining and beneficiation stages, the roasting stage is free from fuel consumption and GHG emissions, as the model considers that the roasting is processed under ideal conditions. In this case, oxidation can sufficiently provide the process heat and no extra heat source is required. In reality, a small amount of fuel is required at the beginning of the roasting to start the process and at the end of the roasting process to make a final temperature adjustment of the outgoing product. Thus, the fuel consumption is highly dependent on the operational conditions. Besides, the inventory consumption in the roasting stage, such as injection air, is more dependent on the concentrate grade than the raw ore grade and mine type, since the concentrate grade is at a relatively constant level between 51 and 58\%. In the roaster, more than $90 \%$ of the input energy or oxidation heat goes into the flue gas because large amounts of air are injected to oxidize and cool the molybdenum ore material, as shown in ESM-Table 6.

Similarly, the smelting process is dependent on the concentrate grade. A large amount of chemical reaction heat will be released during smelting stage (see ESM, Table 6). This means that less external energy is required for heating the smelter. In the smelting process, more than $83 \%$ of the energy and more than $73 \%$ of the GHG emissions originates from the upstream processes producing raw materials such as $\mathrm{FeSi}, \mathrm{Al}$, and lime. The rest is from the extra energy source electricity used by the furnace.
Table 5 Energy consumption and GHG emission of different ferroalloys from reference [38] together with results for FeMo from the present study

\begin{tabular}{llllll}
\hline & FeMn & FeNi & FeSi & FeCr & FeMo \\
\hline Ore grade (\%) & - & 1.3 & - & 25.5 & $0.03-0.21$ \\
Alloy grade (\%) & 77 & 30 & 76 & 53 & 60 \\
Energy (GJ/t ferroalloy) & 48 & 325 & 90 & 77 & $29.1-188.6$ \\
GHG (tCO -eq/t ferroalloy) & 1.77 & 13.9 & 3.44 & 3.04 & $3.16-14.79$ \\
\hline
\end{tabular}

The transport stage consumes $<3 \%$ of the total energy for all cases. Consequently, $<6 \%$ of the total GHG emission comes from the fuel consumption during transporting processes, which has the least environmental impact of all stages for producing one tonne of FeMo.

\section{Discussion}

The mine types and variation of ore qualities are of importance when making life cycle inventory studies for producing ferromolybdenum. It is usually resource consuming to conduct the standard LCI study for each individual plant. Thus, the developed process model is feasible to be used by steel producers to estimate the energy consumption and greenhouse gas emission for FeMo products from different suppliers with a limited input data.

It is inevitable that the higher-grade reserves are extracted first and that the high-grade ores are depleted over time. As the ore grade deteriorates, the energy consumption and GHG emissions for primary FeMo productions will obviously increase. However, one approach to reduce the GHG emissions during FeMo production can be a change of energy sources. Today, the mining and beneficiation stages are largely fossil fuel based. In the present study, case A's diesel use made up of $93 \%$ of the overall energy consumption during the mining and beneficiation stages. During the carbon emission factor of the diesel, fuel consumption in case A for a stationary and a mobile combustion are $70.33 \mathrm{gCO}_{2}$-eq/MJ and $70.44 \mathrm{gCO}_{2}$-eq/MJ, respectively. If the diesel is replaced by nuclear electricity in case $\mathrm{A}$, which has a much lower carbon emission factor $1.667 \mathrm{gCO}_{2}$-eq/MJ, it will reduce the emission in the mining and beneficiation stages from $12.06 \mathrm{tCO}_{2}$-eq/t FeMo to $1.58 \mathrm{tCO}_{2}$-eq/t FeMo. The resulting GHG reduction is therefore as large as $87 \%$.

Additionally, the energy consumption and GHG emission of FeMo from the present study are shown in Table 5, together with LCA results of other common ferroalloys based on average process data [38]. It can be observed that both energy and GHG emission show distinct variations among different alloys. The purpose of Table 5 is not to compare the ferroalloys per se, but rather to underline 
the feasibility to provide indicative results when lacking actual production data. In other words, the methodologies employed in the present study could be used in the analysis of energy consumption and GHG emissions from other ferroalloys, such as FeMn, FeNi, FeSi, and $\mathrm{FeCr}$ in Table 5, to shed some light on the influence of different mining and processing routes.

\section{Conclusion}

In this paper, a case study was carried out to evaluate the energy consumption and greenhouse gas emissions during pyrometallurgical production of FeMo. Four cases were selected to assess the effect of the beneficiation degree, mine type, and production stage on the final commercial ferromolybdenum product's energy consumption and GHG emission. The most important findings from this study may be summarized as follows:

- Among cases A, B, and C, the total energy consumption of producing one tonne of FeMo $(60 \% \mathrm{Mo})$ varies from 29.1 GJ/t FeMo to $188.6 \mathrm{GJ} / \mathrm{t}$ FeMo, while the overall $\mathrm{GHG}$ emission varies from $3.16 \mathrm{tCO}_{2}$-eq/t FeMo to $14.79 \mathrm{tCO}_{2}$-eq/t FeMo. The main variance comes from the mining and beneficiation stages. During these stages, the consumed energy varies between $3.6 \mathrm{GJ} / \mathrm{t}$ FeMo and 162.8 GJ/t FeMo, while the associated GHG emission varies between $0.46 \mathrm{tCO}_{2}$-eq/t FeMo and $12.06 \mathrm{tCO}_{2}-$ eq/t FeMo. The fluctuations are affected by the beneficiation degree and the mine type, i.e., the allocation of co-products from copper mining.

- The effect of mine type on the energy consumption and the GHG emissions of FeMo's production is more influential than the beneficiation degree. Among all the four cases, the co-product in Case D produces FeMo with the lowest energy consumption and least GHG emission.

- The initial ore grades and mine types have very little influence on the downstream roasting and smelting processes, since these processes are dependent on the concentrate grade. This, in turn, is relatively constant for all the cases.

- The transport stage accounts for less than $3 \%$ of the overall energy consumption for all cases. Less than $6 \%$ of the total GHG emission comes from the fuel combustion during the transporting process, which has the least impact of all stages in producing one tonne of FeMo.

Acknowledgements Open access funding provided by Royal Institute of Technology.
Open Access This article is licensed under a Creative Commons Attribution 4.0 International License, which permits use, sharing, adaptation, distribution and reproduction in any medium or format, as long as you give appropriate credit to the original author(s) and the source, provide a link to the Creative Commons licence, and indicate if changes were made. The images or other third party material in this article are included in the article's Creative Commons licence, unless indicated otherwise in a credit line to the material. If material is not included in the article's Creative Commons licence and your intended use is not permitted by statutory regulation or exceeds the permitted use, you will need to obtain permission directly from the copyright holder. To view a copy of this licence, visit http://creativecommons.org/licenses/by/4.0/.

\section{References}

1. Four Elements Consulting, LLC (2018) Life cycle inventory of molybdenum products for metallurgical applications, update study-summary report. International Molybdenum Association

2. Kennecott Utah Copper (2006) Kennecott Utah Copper molybdenum oxide environmental profile-life cycle assessment. Kennecott Utah Copper

3. Castro-Molinare J, Korre A, Durucan A (2014) Sustainability analysis of copper extraction and processing using life cycle analysis methods: a case study in the North of Chile. Comput Aided Chem Eng 33:1861-1866

4. Muthu SS (2014) Chapter 6-Estimating the overall environmental impact of textile processing: life cycle assessment (LCA) of textile products. In: Assessing the environmental impact of textiles and the clothing supply chain. Woodhead Publishing, Amsterdam, pp 105-131

5. Swinbourne DR, Arnout S (2018) Thermodynamic model of metallothermic smelting of ferromolybdenum. Miner Process Extr Metall 128(3):1-12

6. Lessard JD, Shekhter LN, Gribbin DG, Mchugh LF (2013) Thermodynamic analysis of looping sulfide oxidation production of $\mathrm{MoO}_{2}$ from molybdenite for energy capture and generation. JOM 65:1566

7. Tsalapatis $\mathbf{J}$ (2000) Application of an online heat and mass balance model to an ironmaking blast furnace in School of Geoscience, Minerals and Civil Engineering. University of South Australia

8. Eckelman MJ (2010) Facility-level energy and greenhouse gas life-cycle assessment of the global nickel industry. Resour Conserv Recycl 54(4):256-266

9. Qi Z, Gao C, Na H, Ye Z (2018) Using forest area for carbon footprint analysis of typical steel enterprises in China. Resour Conserv Recycl 132:352-360

10. Camdali U, Tunc M (2016) Calculation of chemical reaction energy in an electric arc furnace and ladle furnace system. Metallurgist 60(7):669-675

11. Gyllenram R, Jönsson PG, Ekerot S, Persson F, Ternstedt P (2011) Taking in house and upstream $\mathrm{CO}_{2}$ emission into account in charge optimization for scrap based steelmaking, METEC InSteelCon 2011 proceedings, Düsseldorf, Germany

12. Gutiérrez AS, Martínez JBC, Vandecasteele C (2013) Energy and exergy assessments of a lime shaft kiln. Appl Therm Eng 51(1):273-280

13. Liu P et al (2016) Material and energy flows in rotary kiln-electric furnace smelting of ferronickel alloy with energy saving. Appl Therm Eng 109:542-559

14. Luong VT et al (2018) A comparison of carbon footprints of magnesium oxide and magnesium hydroxide produced from conventional processes. J Clean Prod 202:1035-1044

15. United States Geological Survey (2017). 2014 Minerals Yearbook-Molybdenum. United States Geological Survey Web. https 
://s3-us-west-2.amazonaws.com/prd-wret/assets/palladium/ production/mineral-pubs/molybdenum/myb1-2014-molyb.pdf. Accessed 18 Sept 2019

16. Jha MC (2001) Extractive metallurgy of molybdenum. In: Mishra B (ed) Review of extraction, processing, properties \& applications of reactive metals. The Minerals, Metals \& Materials Society, pp $73-82$

17. Gasik M (2013) Chapter 12 - Technology of Molybdenum Ferroalloys. In: Handbook of Ferroalloys, Butterworth-Heinemann: Oxford pp 387-396.

18. Fthenakis V, Wang W, Kim HC (2009) Life cycle inventory analysis of the production of metals used in photovoltaics. Renew Sustain Energy Rev 13(3):493-517

19. Barin I, Knacke O (1973) Thermochemical properties of inorganic substances. Springer, Berlin

20. Kirschen HPM (2002) Thermodynamic analysis of EAF electrical energy demand, 7th European electric steelmaking conference, Venice

21. Northcott L (1956) Molybdenum. Butterworth, Metalllurgy of the rarer metals

22. United States Geological Survey (2017). 2014 minerals yearbookChina. United States Geological Survey Web. https://s3-us-west-2. amazonaws.com/prd-wret/assets/palladium/production/mineralpubs/country/2014/myb3-2014-ch.pdf. Accessed 18 Sept 2019

23. Thompson Creek Mine (2013) Air permit application to convert tier II operating permit to a permit to construct. Thompson Creek Mining Company

24. Cappa JA et al (2006) Colorado Mineral and Energy Industry activities, 2005. Colorado geological survey web. https://color adogeologicalsurvey.org/wp-content/uploads/2013/08/MMF20 05.pdf. Accessed 18 Sept 2019

25. Nair KU et al (1987) Chlorination of commercial molybdenite concentrate in a fluidized bed reactor. Metall Trans B 18(2):445-449

26. China Molybdenum Co., Ltd (2018) Semi-annual report for 2018. China Molybdenum Co.,Ltd Web. https://www.chinamoly. com/06invest/doc_a/2018/603993_2018_zzy.pdf. Accessed 18 Sept 2019

27. Krahulec K (2018) Production history of the Bingham mining district. Salt Lake County, Utah - an update. https://doi.org/10.13140 /RG.2.2.28618.00966

28. Norgate T, Jahanshahi S (2006) Energy and greenhouse gas implications of deteriorating quality ore reserves. 5th Australian conference on life cycle assessment

29. Norgate T, Rankin W (2000) Life cycle assessment of copper and nickel production, International Congress on Mineral Processing and Extractive Metallurgy. Melbourne, The Australasian Institute of Mining and Metallurgy

30. Benavides PT, Dai Q, Sullivan J, Kelly J, Dunn JB (2015) Material and energy flows associated with select metals in GREET2: molybdenum, platinum, zinc, nickel, silicon. Argonne national laboratory web. https://greet.es.anl.gov/publication-mo-pt-zn-nisi. Accessed 18 Sept 2019

31. Lelinski D, Govender D, Dabrowski B, Traczyk F (2011) Effective use of energy in the floatation process, 6th Southern African base metals conference 2011. The Sourthern African Institute of Mining and Metallurgy Web. https://www.saimm.co.za/Conferences/ BM2011/137-Mulligan.pdf. Accessed 18 Sept 2019

32. Schulz KJ et al (2017) Critical mineral resources of the United States: economic and environmental geology and prospects for future supply. United States Geological Survey Web. https://pubs. usgs.gov/pp/1802/pp1802_entirebook.pdf. Accessed 18 Sept 2019

33. U.S. Environmental Protection Agency (1992) Mine site visit: Cyprus Thompson Creek. U.S. Environmental Protection Agency Web. https://archive.epa.gov/epawaste/nonhaz/industrial/special/ web/pdf/phosmol2.pdf. Accessed 18 Sept 2019

34. International Energy Agency (2017) Average freight energy intensity and activity in 2015, International Energy Agency Web. https ://www.iea.org/newsroom/energysnapshots/average-freight-energ y-intensity-and-activity.html. Accessed 18 Sept 2019

35. U.S. Energy Information Administration(2019) How much of U.S. carbon dioxide emissions are associated with electricity generation? https://www.eia.gov/tools/faqs/faq.php?id=77\&t=11. Accessed 18 Sept 2019

36. IPCC (2013) Climate change 2013: the physical science basis. Contribution of working group I to the fifth assessment report of the intergovernmental panel on climate change, IPCC web. https ://www.ipcc.ch/report/ar5/wg1/. Accessed 18 Sept 2019

37. China Molybdenum Co., Ltd. (2019) Molybdenum concentrate. China Molybdenum Co., Ltd. Web. https://www.chinamoly.com/ en/03products/detail_mujingkuang.htm. Accessed 18 Sept 2019

38. Haque N, Norgate T (2013) Estimation of greenhouse gas emissions from ferroalloy production using life cycle assessment with particular reference to Australia. J Clean Prod 39:220-230

Publisher's Note Springer Nature remains neutral with regard to jurisdictional claims in published maps and institutional affiliations. 